\title{
Max Weber, Islam, and Rationalization: A Comparative View*
}

\author{
TOBY HUFF**
}

Max Weber, islám a racionalizace: komparativní pohled

\begin{abstract}
From his early studies, beginning with the Protestant Ethic and the Spirit of Capitalism, Weber began to realize that religious orientations provide strong motivations to reshape, or rationalize the mundane world. He then found that rationalist inclinations also affected music and the arts, and thus seemed to penetrate all spheres of artistic, social, and political life. At the same time Weber's inquiries deep into the history of law back to the Romans illustrated the same process of making the European legal system more systematic, logical, and tightly integrated. This resulted in a whole range of legal innovations such as constitutionalism, parliamentary democracy, elections by consent, a clearly defined notion of due process of law, the invention of legally autonomous corporate entities, and much more. This network of legal constructions I refer to as the hidden structure of modernity, greatly overlooked because of its being taken for granted. However, when a comparison with the development of Islamic law is undertaken, we discover that its legal rationalization led in an entirely different direction.
\end{abstract}

Keywords: Max Weber; civilizations; rationalization; law; Islam; West

DOI: $10.14712 / 23363525.2019 .7$

Students of Max Weber's larger agenda of civilizational studies (those focused on the domain-effects of the five great world religions, plus Judaism), have understood that the concept of rationalization was central to his deeper insights. ${ }^{1}$ For Weber, this idea referred to a broad socio-cultural process characterized by the growth of rationality, of logically and systematically integrated units of the social and cultural organization. This occurred in such spheres as law, economy, science, and polity. However, not all rationalizing forces in contracting civilizations would end up producing the same configurations of meaning.

What is most remarkable in Weber's perspective is the fact that he looked to religion, not to a pervasive scientific ethos or the legacy of Hellenism, for the sources of reason and rationality, both in "East" and "West." One can see that this insight followed from Weber's initial discovery that Protestant Christianity had sparked what Weber identified as the "Protestant ethic" (obviously flowing out of the Reformation) that increasingly took the form of inner-worldly asceticism. This orientation increasingly assumed the form of impersonal service dedicated to rational mastery of the world, or "the rational organization of our social environment" [Weber 1958: 109]. In other words, a key motivational driver

* This lecture has been presented at the Department of Historical Sociology, Faculty of Humanities at Charles University in Prague, on the 2nd November 2017.

** Toby Huff, Harvard University, Faculty of Arts and Sciences, Cambridge, MA 02138, The United States. E-mail: thuff@fas.harvard.edu.

1 For the canonical sources for the reconstruction of Weber's thought along these lines, see Schluchter [1979, 1981, 1989]. 
of the energy of modern capitalism appeared to come from this religious source. A more general formulation of this insight has been called the "theodicy problem," namely, if the world were to have religious meaning, what would it look like and how should we go about organizing our mundane world? In that sense, all religious persuasions have an inherent inclination to rationalize or mold the social order in the service of religious interests [Weber 1964: chapter 9]. ${ }^{2}$

It then dawned on Weber around 1910 that he should undertake a set of comparative studies of "economic ethics" that might be found, differently concatenated, in the great world religions, i.e., Confucianism, Buddhism, Hinduism, early Christianity, Islam, and ancient Judaism. This launched Weber into his nonpareil sociology of religion. Moreover, Weber credited ascetic Protestantism with spurring the development of modern science and with the specific contribution of placing "science in the service of technology and economics" [Weber 1961: 270].

The second breakthrough in Weber's masterwork, as Wolfgang Schluchter and others have pointed out, came from another entirely unsuspected direction, that is, the history of music. It was then (around 1910-11) that he discovered how Western music is heavily dependent on a deeply embedded rationale of logical and mathematical relationships to produce the tones that are pleasing to Western ears. For Weber, this meant that there is something unique about Western rationality in general, that it has been applied to virtually all domains, not just those most associated with practical action, economics or technological innovation [Schluchter 1989: 418]. ${ }^{3}$

In a word, Marianne Weber noted that her husband's discovery of the pervasive influence of rationalism throughout all the domains of Western culture emerged from the study of the history of music, and "precisely in music - an art form which seemingly flowed directly from the emotions" where "reason played such an important role," giving Occidental music its uniqueness. Whatever the multiple sources of this unique Occidental rationalism, they could be found at play in all the spheres of human action in the Western world, including the arts and music. From then onward Weber saw the unique shape of the European cultural world "not only in economic development, but in scientific, artistic, and political development" as well [ibid.: 430].

Given this sketch of Weber's intellectual journey on the way to recognizing the powerful influence of rationalizing forces in Western history, I want to turn to the sphere of law and legal development. As we know, the domain of law was another of Weber's major concerns where the uniqueness of Western rationalism seems most salient. Furthermore, Weber understood that both capitalism and the modern political order rested on unique legal foundations. While he seemed to suggest that various patterns of legal development occurred universally, he also observed that "systematization" [in law] "has never appeared but in the late stage of legal modes of thoughts" [Weber 1954: 62]. ${ }^{4}$

2 All the ways in which religious interests attempt to shape and mold the many spheres of social life were spelled by Weber in his extraordinary essay, "Zwischenbetrachtung," or "Intermediate Reflections" [see Gerth - Mills 1946: chapter 13].

3 Which discovery had also been pointed out by Marianne Weber in her biography [1975].

4 Also: "The specially modern form of systematization, which developed out of Roman law, has its points of departure in the logical analysis of the meaning of the legal propositions as well as the social actions" [ibid.: 62]. 
However, as in so many areas in which Weber labored with great intensity, his study of comparative legal systems was unfinished, with the result that some of his comparisons were but sketches (especially in Economy and Society, Chapter VIII, section v). In addition, Weber's matrix of comparison centered on the differences between formal versus substantive rationality. This might not have been the best access point for laying bare the profound developmental differences, for example, between medieval European law and Islamic law. Nevertheless, I want to suggest that a comparison between European legal development and Islamic law in the late medieval era reveals the very different workings of rationalization in the two legal traditions and civilizational contexts.

On the one hand, we shall see that the contrasting stasis of Islamic sacred law (the sharia), had profound consequences for both intellectual and economic development. On the other hand, dynamic Western legal development from the medieval period onward has been far more important for Western development broadly - in the economy, polity, and science - than has been recognized previously. I shall suggest that these unique legal developments constitute the hidden structure of modernity, and they can only be detected by a comparative analysis such as I have undertaken elsewhere [Huff 2017: chapter 3 and 4].

\section{The World of Islam}

It goes without stressing that Weber's writings on Islam at the beginning of the twentieth century were only as good as his sources. In addition, due to Weber's habits of work and the unfinished nature of his studies of Islam, it has been difficult to track down all the sources that he used. Cleary today, 100 years later, we know a great deal more about the Middle East and the Muslim world than what was known in $1920 .{ }^{5}$ Consequently, I shall focus on the current standard view of Islamic law and religious teachings that were prevalent during the first several centuries of Islam.

As I have suggested elsewhere, the early founders of Islamic civilization following the death of the prophet Muhammad (in 632 C.E.) and from a social engineering point of view, had to accomplish three tasks [Huff-Schluchter 1999: chapter 3].

The first was to establish a standard set of dogmatic statements laying out the rudiments of Islamic belief that were more concise than the 114 chapters (suras) of the Quran.

The second task entailed a more philosophical and hence theological explanation of the fundamental beliefs of Islam. This was necessary because of the ambient Greek philosophical culture that was still shaping dialogues with Christians, Jews, and other non-believers. This gave birth to kalam (theology), Islamic religious philosophy.

The third task should have been creating a stable political order based on some kind of constitution and legal accords for passing on the rulership of the Islamic regime. More broadly, this was the domain of law that did get fleshed out during these same two formative centuries but did not establish a formal mechanism for power transition, nor clear and consistent ideas of due process.

These tasks were taken up by a variety of thinkers across the expanding Muslim community who were far from coordinated, thereby provoking controversy and dissent that

5 For an attempt to assess Weber's studies of Islam at the end of the twentieth century, see a book chapter Hindrances to Modernity: Max Weber on Islam [Huff-Schluchter 1999: 53-138]. 
further propelled discussion. The standard edition of the Quran itself did not appear until 22 years after the death of Muhammad. Likewise, the compiled sayings (hadiths) of Muhammad did not start appearing until about 60 years after the prophet's death; ${ }^{6}$ but once these sources of belief emerged, others set to work creating the larger narratives that were thought necessary [see Crone 2004].

The task of providing a concise set of orthodox beliefs was undertaken by those seeking to construct a short set of creeds that expressed the central message of the Quran. This was done during the first two centuries of the rise of Islam. Today only highly educated Muslims across the Islamic world know these creeds, whereas most Muslims know the fatiha (the "opener") and a few other passages from the Quran [for discussions of creed formation, see Watt 1994; Wensinck 1932; Cook 2003].

Apart from those formal creeds, the simplest representation of the core of Islamic belief and practice is composed of the five pillars: prayer five times daily; recitation of the shahadah ("there is no god but god and Muhammad is his messenger"); fasting during the month of Ramadan; paying the poor tax (zakat); and pilgrimage (haj) to Mecca once in one's lifetime.

Beyond these modest obligations, it is the sharia, Islamic law, that is at the heart of Islam. From a spiritual point of view, it is also known as "the straight path to salvation" with the assumption that the Quran is a complete "book of knowledge" providing guidance for Muslims on all occasions and in all circumstances. These two sources, the Quran and the hadith collections (or sunna), comprise the central structure of Islam governing all aspects of human behavior. In that sense, they constitute a prescriptive or legal system. Consequently, only those trained in legal arcana - the sharia - are thought to be qualified to say whether some particular form of behavior is Islamic or not. This suggested that the believer should consult a legal scholar whenever a question of appropriate Muslim behavior arose. These two elements, then, the Quran hadiths, formed the governing structure, the intellectual grid or matrix of Islam that was put into force during the early formative years of Islamic civilization. ${ }^{7}$

From this legalistic point of view, whenever some new form of behavior or the use of some new item of technology comes into question, the good Muslim must answer this question: is the behavior (or technology) in question, 1) obligatory, 2) recommended, 3 ) permissible, 4) reprehensible, or 5) forbidden? Clearly only a literate person and legal specialist could answer such a question. This matrix continued to be employed into the twentieth century when discussions about such issues as postmortem autopsies and organ transplants were considered [Huff 2002].

There were other philosophical points of view that emerged, those raised especially by the party of disputation, the mutakallimun (religious philosophers), who sought to engage in philosophical disputations that grew out of the Greek philosophical tradition that was embedded in the larger literature of the many Greek scientific and philosophical works

6 The six canonical collections of hadiths include the following: those of al-Bukhari (died 870); Muslim b. al-Hajjaj (died 875); Abu Da'ud (died 888); al-Tirmidhi (died 892); al-Nasai (died 915); Ibn Maja (died 886). The number of separate entries ranged about 6000 to over 9000. Also see Ibn Warraq [1998].

7 Here I must forgo discussion of the "roots of law" and the permissible modes of reasoning that are allowed with regard it's elaboration or modification [for more see Huff 2017: 92-96; Rahman 1979: chapter 4; Schacht 1964]. 
that were translated into Arabic in the eighth to the 10th centuries [see for more Huff 2017: 96-98; Gutas 1998]. This strand of thought is usually traced through the mu'tazilites, the so-called Islamic rationalists, who thought that reason in a Western sense had a commanding role in religious and philosophical debates in the early formative years [among many other sources on this, see Watt 1974; Frank 1992: 7-37; Crone 2004: 65-99]. In the end, however, this school of thought was defeated with the result that philosophical and theological discussions were pushed aside, leaving the legal scholars, the fuqaha (or muftis) as the dominant intellectual arbiters. This was spelled out by the great and unsurpassed legal scholar alAshari (d. ca 935). He made it clear that there was a sharp division between the domain of law and that of religious thought:

The [early generations] have discussed and disputed about such matters as arose at that time concerning Din [religion] from the side of the shari'a (i.e., law) ... like the legal duties such as punishments and divorce which are too numerous to mention here ...

Now, these are legal matters which pertain to details of life which they (i.e., the early generations) brought under the shari'a which concerns itself with the detailed conduct of life and hence can never be comprehended except on the authority that comes from the Prophets. But as for the matters that arise in the field of the principles for the determination of questions (of Faith) every intelligent Muslim must refer these to the general and agreed on principles founded upon reason, sense experience, and immediate knowledge, etc. Thus the questions of details of the shari'a (i.e., law), which are based on traditional authority must be referred to the principles of the sharia whose source is traditional authority, whereas questions arising out of reason and experience must be referred to their own bases, and authority and reason must never be mixed up. ${ }^{8}$

This point of view became orthodox throughout the Muslim world and lasted all the way to the end of the twentieth century. This meant that philosophers and ethicist had at best a minor role to play in the religious disputes that erupted throughout Islamic history. Thus fiqk (legal scholarship) not kalam (theology) became the decisive discipline that became the central subject in all madrasas across the Muslim world ever after. Moreover, as Fazlur Rahman perceived, Islamic thought did not generate a discipline of "Islamic ethics" so that legists remained the intellectual arbiters of Islamic thought thereafter [Rahman 1979: 256f; 1982: 154f].

\section{Law and Legal Rationalization}

As we saw earlier, one critical dimension of Western development has been the emergence of the unique European system of law. Although it has its roots in Roman law and the latter's millennium-long history of development, the great formative period of Western legal development occurred in the late medieval period. This has been spelled out by many legal historians, especially Harold Berman [1983]. ${ }^{9}$ All the major Western legal traditions, i.e., Canon law, the Civil law tradition, the ius commune, and the Anglo-British Common law tradition evolved out of these earlier roots. To grasp how very different the Western legal tradition was from the Islamic tradition, one would need to examine both substantive

Al-Ash'ari as cited in Rahman [1979: 105].

9 More sources will be cited below. 
and procedural law (along with other branches). Here I shall mainly focus on procedural issues, for it is this domain marked by the formal "rule of law" that one generally looks to as the demarcator of Western versus other forms of "justice."

If we go back to Islamic law and look at it in a little detail, we can see the ways in which Islamic law went in a different direction, ultimately making very little progress in comparison to the profound legal changes Europeans made during the medieval period.

\section{Islamic Law}

For some time there has been a dispute among Islamic scholars as to whether the so-called closing of the gate of jtihad ("intellectual struggle") inhibited Islamic legal development.

Some scholars have disputed this. While accepting the idea that the gate of ijtihad had been closed, Herbert Liebesny qualified that statement by asserting: "This event may have slowed but did not prevent the further development of law based on consensus [ijma] and analogy [qiyas] accomplished primarily through the legal opinions or fatwas of the muftis" [1983: 203; see also Masud - Messick - Powers 1996]. Indeed, he averred, the "fatwas of the muftis were a very important factor in the development of the law" [ibid.: 215].

There is a very large terrain of comparisons that we could consider here, but I shall confine our attention to procedural questions, to what we call due process of law.

The first thing we must notice is that Islamic law had no functionary such as a lawyer or advocate who could be officially charged with aiding or defending the plaintiff or the defendant in a legal proceeding [Jennings 1975]. One could ask for a hakim, a sort of legal helper, but he was not a trained lawyer; he could be a relative, a neighbor, or another literate person. Moreover, as a representative of the defendant, his testimony could be substituted for that of the actual witness, which could mean that the hakim would ignore the actual testimony of the witness while inserting his own [see Powers 2002: chapter 1]. Likewise, he was not "a member of the bar" as became the case for lawyers in Europe in twelfth and thirteenth Century nor did he have to be a graduate of a madrasa [Brundage 2008].

In addition, the keeping of records by Islamic judges was totally irregular, as there was no official repository of court cases until the end of the sixteenth century. The Qadi kept his own records, which were never published. In addition, the actual verdict reached by the Qadi, the judge, was given only to the two parties, and never officially recorded or published. The idea was that every judge should be permitted to reach his own decision. Probably it is this context to which Weber and other early twentieth century scholars spoke when referring to "Qadi justice" and the Islamic judge "sitting under a tree" while handing out decisions [for the informal nature of the Qadi's court, see Messick 1993; Powers 2002: chapter 1]. The kernel of truth in this context is that a judge was free to make any decision he wished because there was, intentionally, no sense of precedent, no evolving legal standard. Even in the late twentieth century in Afghanistan, traditional judges felt the same way: that is, if you record judicial decisions (in the interest of uniformity of treatment), then you will turn Islamic law into Common law as in England with its tradition of judicial precedents, and we Muslim surely do not want that [this is illustrated by Csaplar 1976]. ${ }^{10}$

10 Also personal communication. 
However, there is another form of judicial decision-making mentioned above by Liebesny, that is the fatwa. But these statements are nonbinding legal opinions issued unofficially by legal scholars in response to questions put to them informally (about correct behavior) by an individual Muslim, or possibly by a Qadi contemplating a case. Such written replies (fatwas) could be followed by a private individual and/or could be considered by a judge in making his decision, but they are in no sense obligatory and do not form an official court record. Indeed, an individual could apply to several different muftis (legal scholars) and ask for an opinion about some ethical or religious behavior and then decide which if any he would follow. And since there were four major schools of law, ${ }^{11}$ one could go to each of them for an opinion, or maybe two different muftis from the same school of law.

Without going into further detail here, we can see that there was a great deal of procedural vagueness in Islamic law because it was in no sense codified, but rested on a wide field of interpretations of the Quran, as well as conjectures about what scholars surmised the practice of Mohammad had been during his life time. Despite the vagueness of conjectures about the practice of Muhammad, it was the gold standard for Islamic judicial practice all the way to modern times.

In short, this reliance on the unyielding traditional interpretations, grounded in the Quran and the sunna, lasted all the way to the eighteenth and nineteenth centuries. One can look at the various standard Islamic law books of later times (sixteenth and seventeenth centuries, and in some cases, the 20th century) but one will find that these writers did not introduce any innovations regarding standard juridical procedures [for more see Huff 2017: 129-135, 136-138].

\section{The Evolving European Legal Tradition}

To grasp the significance of this state of affairs in Islamic law, we need to look at the contrasting patterns of development in Europe. There, in the twelfth and thirteenth centuries, we find an entirely different outlook and process that struck Max Weber very profoundly. Still confining our attention to the legal sphere, what we see in Europe is a revolutionary transformation that affects virtually every sphere of daily life - economy, polity, banking ownership, self-governance, and legal autonomy. Plainly, this is the origins of constitutionalism and institutional democracy, due process of law and so on - none of which occurred in the Islamic legal system for more [for more on the sweeping legal reform in Europe see Huff 2017: chapter 4].

First, I should mention that in the eleventh century, northern Europeans discovered the lost manuals of Roman Law - the so-called Roman Corpus Juris Civilis. This brought about a radical awakening among legal scholars because this system was far larger, more systematic and more comprehensive than anything northern Europeans had known since the collapse of the Western portion of the Roman Empire in about 476. Many legal scholars in Italy obtained copies of these manuscripts and began probing and glossing them. In the end, they transformed it into a legal system of the church (Canon law), and also Civilian law, that was used outside the Church in secular settings. There were many outstanding

11 The Maliki, Shafi'i, Hanbali, and Hanafi. See Schacht [1964] and Hallaq [2005]. 
scholars who did this, but special praise goes to a monk named Gratian (d. ca 1142), who poured over this new legal system and worked systemically to figure out: a) what are the basic principles of this ancient legal system; and b) how can we to integrate Christian church law, Biblical law, German folk law and a several folk-law traditions into this older but highly developed legal system? His efforts produced the extraordinary Concord of Discordant Canons, a formal foundation for the newly emerging European Romano-Canonical system [Gratian 1992].

In a word, the legists sought to create a more systematic, coherent and legally justifiable system. This became the very foundation of all modern international law. This it seems to me, is a splendid example of what Weber described as a rationalization - making things far more inclusive, comprehensive and logically integrated. They also worked out legal precedents that were presumed to be binding on all courts. Most of these changes were at best tacitly acknowledged by Weber. There is no question, however, but that he understood that the reception of Roman Corpus Juris Civilis had a profound effect on the formation of Western law ever after.

Furthermore, since this was the time of the founding of the European universities, the legal scholars now began to teach this revised and reformed Romano-canonical law in the universities.

If we stay with this comparison with Islamic procedural law, we discover in Europe a set of paradigmatic procedures that were spelled out in detail especially by the canonists, the Church lawyers. This new system - now called the ius commune, i.e., the common law of the European Continent - was used wherever the Christian church spread, thereby becoming the universal legal system of Europe, the system used in England and across the Continent [among others see Stein 1999; Hartmann - Pennington 2008; Hartmann Pennington 2016]. Civilian lawyers were trained in it because they might have to defend someone in an ecclesiastical court. In England at this time, many of the clerks, the legally trained servants in the royal courts, were often Christian ecclesiastics.

Furthermore, European legal doctrine (that was articulated by scholars in legal treatises, was established in court cases and articulated in Papal decretals), expected that every trial must involve a plaintiff and a defendant, that is, advocates for those two parties, the appearance of witnesses, the presence of court recorders such as clerks, proctors and notaries. These latter officials recorded the whole proceedings along with the names of those present at the trial and so on [Brundage 2008: chapter 10].12 This was established a legal procedure by the end of the 12th century - all worked out by legal scholars usually attached to the schools and emerging universities, but also papal canonists. It was not just worked out as a matter of "customary practice" but ensconced in major textbooks, such as Tancred's Ordo iudicale [i.e., Legal Procedure] [1214-16] and Durand's Mirror for Judges (Speculum iudiciale) [ca.1271]), and in Papal letters and statements (concilia) circulated across Europe. These documents were then taught in the law schools of the universities. This process is at the heart of what legal historians saw as the emergence of the ius commune, the common law of Europe [among others see Helmholtz 1996: 222-231; Hoeflich Grabler 2008; Stein 1999; Brundage 2008; Hartmann - Pennington 2018].

12 Tancred: "the service of advocates is essential in lawsuits," as cited in Brundage [2008: 171]. 
It is also notable in our context that virtually all records, whatever they are, the initial complaint to the court (the libellius), summonses, testimony, reports or contracts presented, were recorded and filed away. This official evidence was also read out aloud in court and these records became part of the official court records, kept by proctors or notaries in an official location, always bearing the signature or seal of the acting court official. This was unlike the situation in Islamic law where records were, at best, irregularly maintained by the judge or his clerk in the "qadi's diwan" [Hallaq 1998], his private files usually maintained in his home. ${ }^{13}$

But there is more: the opposing advocates prepared a list of questions to be put to the witnesses by the judge (or official examiner) for close questioning individually in private. Every effort was made, in the first instance by the interrogatories provided to the judge and by the opposing attorneys to separate direct evidence from hearsay testimony. The witnesses were sworn before god to tell "the whole truth and nothing but the truth about everything they knew in connection with the action in which they were to testify" [Brundage 2008: 436]. They were also cautioned to testify only about events they had seen and heard, "but not about what they believed or thought they heard from others." This was oath-taking, to tell the truth, not an oath defying God and threatening punishment in the afterlife for falsehoods. As Harold Berman pointed out, this was a new legal conception introduced into canon law by Europeans of this era [Berman 1983: 250]. ${ }^{14}$

An example of such close questioning comes from the Canterbury Court of England in the 13th century in the case of Master Robert de Picheford concerning the ownership of a church in the Diocese of Lincoln. The interrogatories submitted on behalf of the defendant Thomas de Nevill stated.

First, the examiners are to hear what the witnesses say of their own motion and to inquire as to the source of their information about each of the articles [submitted by Master Robert]. If they say that Robert was in possession of the church of Houghton as rector by himself or others from 26 July to 3 August 1268, they are to be asked whether they know this from seeing, hearing, knowledge, belief or public report. If they say seeing, ask where, when, the nature of the possession whether natural or civil, mental or physical, and how long before the feast Robert possessed the church and whether continuously or at intervals [Adams - Donahue 1981: 269].

Proctors or notaries, who were sworn officers of the court, were charged with recording all testimony and copying any other material presented to the court. When all testimony was completed, it was to be read out loud in front of the opposing parties by the judge or court official.

13 It should also be noted that in the European system the procedures specified that each court was meant to run according to a calendar, that once the plaintiff's complaint was presented, the presiding judge would establish a date for a hearing along with specified sessions for the hearing of the testimony of witnesses. All proceedings were determined by a court schedule, not the whim of the defendant. See Richard Helmholz [1974: chapter 4 and 5]. For the more flexible Islamic procedure, see Powers [2002] and Messick [1993].

14 Oath-taking in Islamic law operated differently: when no evidence or witnesses were available, one could swear an oath, or alternatively, one could swear "50 oaths" and that would end the case or exonerate the accused. See Powers [2002: 162-166] and Ibn Rushd [1994: 261]. 


\section{Conclusion}

What can we now say about Weber's notion of comparative rationalization? First, it is clear that the Western legal tradition has been in the process of change for centuries. It has become ever more developed, comprehensive, and systematic. I would not stress Weber's notion of creating a completely logically coherent and "gapless," system, but it did undergo all sorts of revisions, reforms, clarifications (rationalizations) and additions, while logically integrating a plethora of divergent legal conceptions.

During the twelfth and thirteenth centuries, continuing into the fourteenth and fifteenth centuries (and beyond), Europeans developed what are in fact the fundamental structures of modernity that still prevail, and have traveled, with modifications, around the world.

We see it in our adherence to a set on conventions and protocols that define the very idea of due process of law, actual court room practice, and in myriad ways in daily activities and business transactions that are governed by a large set of underlying legal assumptions about who has done what, who can do what, and how to remedy events if things go wrong.

These protocols, include the notion of legally qualified mediators (lawyers as well as fully trained judges), the creation of legally autonomous entities whether these are cities and towns, business enterprises, self-governing entities of many sorts, parliaments and other official_legislative bodies; the establishment of a constitutional order, conjoined with democratic procedures entailing election by consent (the consent of the governed). All these items have medieval and early modern roots and none of them appeared in Islamic law, nor Chinese law [for this comparison see Huff 2017: 219-235].

Looking at Islamic law, none of the rationalizations of concepts and procedures took place before Islamic law encountered the very different Western legal regime in the eighteenth century and later. At that point, Islamic law as a functioning system was reduced to family law and inheritance.

Furthermore, all of the other spheres of law - urban law, commercial law, criminal law, administrative law, patent law, and so on - remained undeveloped or entirely absent. ${ }^{15}$

The same was true for Chinese law that remained highly static all the way from the Ming through the Qing and its collapse in the first decade of the twentieth century. Chinese law then had to be entirely reconstructed, bringing in, for example, with great reluctance, those trouble makers known as lawyers and called "pettifoggers" into the 1950s [Macauley 1998]. ${ }^{16}$

There is much more to be said, historically, about the unevenness of the rationalization process in one civilization (or society) than another, but I must leave that for another day.

15 For an extraordinary example of the complete absence of due process of law in a contemporary Islamic country, see Sarah Leah Whitson [2017]. The Saudi crown Prince, Muhammad bin Salman, seeking to curb corruption in the kingdom, simply put those accused under house arrest, no official court proceedings required.

16 For contemporary perceptions of China's persecution and incarceration of human rights lawyers, see Rachel E. Stern [2017], Andrew Jacobs and Christopher Buckley [2015], and Alex Palmer [2017]. 


\section{Bibliography}

Adams, Norma - Donahue, Charles [1981]. Selected Cases from the Ecclesiastical Courts of the Province of Canterbury c. 1200-1301. London: The Selden Society.

Berman, Harold [1983]. Law and Revolution, The Formation of the Western Legal Tradition. Cambridge: Harvard University Press.

Brundage, James [2008]. The Medieval Origins of the Legal Professions. Canonists, Civilians, and Courts. Chicago: University of Chicago Press.

Cook, Michael [2003]. Forbidding Wrong in Islam. New York: Cambridge University Press.

Crone, Patricia [2004]. God's Rule. Six Centuries of Medieval Islamic Political Thought. New York: Columbia Press.

Csaplar, Richard [1976]. A Collection of Afghan Judicial Decisions. Mimeograph.

Frank, Richard [1992]. The Science of Kalam. Arabic Science and Philosophy 2 (1): 7-37.

Gerth, Hans - Mills, C. Wright (eds.) [1946]. From Max Weber: Essays in Sociology. New York: Oxford University.

Gratian. The treatise on Laws (Decretum DD. 1-20) [1992]. Translated by Augustine Thompson, O.P. with the Ordinary Gloss, and an Introduction by Katherine Christensen. Washington, D.C.: The Catholic University of America.

Gutas, Dimitri [1998]. Greek Thought, Arabic Culture. The Graeco-Arabic Translation Movement in Baghdad and Early 'Abbasid Society (2nd-4th/8th-10th Centuries). London: Routledge.

Hallaq, Wael [1996]. The "qadi's diwan (sijill)" before the Ottomans. Bulletin of the School of Oriental and African Studies 61 (3): 415-436.

Hallaq, Wael [2005]. The Origins and Evolution of Islamic Law. New York: Cambridge University Press.

Hartmann, Wilfried - Pennington, Kenneth (eds.) [2008]. The History of Medieval Canon Law in the Classical Period, 1140-1234: From Gratian to the Decretals of Pope Gregory IX. Washington, D.C.: Catholic University of America Press.

Hartmann, Wilfried - Pennington, Kenneth (eds.) [2018]. The History of Courts and Procedure in Medieval Canon law. Washington, D.C.: The Catholic University of America Press.

Helmholz, Richard [1974]. Marriage Litigation in Medieval England. Cambridge: Cambridge University Press.

Helmholtz, Richard [1996]. The Spirit of Classical Canon Law. The Athens: University of Georgia Press.

Hoeflich, Michael H. - Grabler, Jasonne M. [2008]. The Establishment of Normative Legal Tests. The Beginnings of the Ius Commune. In. Hartmann, Wilfried - Pennington, Kenneth (eds.). The History of Medieval Canon Law in the Classical Period. Washington, D.C.: Catholic University of America Press, pp. 1-21.

Huff, Toby - Schluchter, Wolfgang (eds.) [1999]. Max Weber \& Islam. New Brunswick: Transaction Books.

Huff, Toby [2002]. Attitudes Towards Dissection in the History of European and Arabic Medicine. In. El Bouazatti, Bennacer (ed.). Science: Locality and Universality. Rabat: Mohammad V University Press, s. $61-88$.

Huff, Toby [2017]. The Rise of Early Modern Science: Islam, China and the West. Cambridge: Cambridge University Press (3rd edition).

Jacobs, Andrew - Buckley, Christopher [2015]. China Targeting Rights Lawyer in a Crackdown. New York Times, July 22, 2015.

Jennings, Ronald [1975]. The Office of Vekil (wakil) in the 17th Century Ottoman Courts. Studia Islamica 42: $147-169$.

Liebesny, Herbert [1983]. Judicial Systems in the Near East and Middle East: Evolutionary Development and Islamic Revival. The Middle East Journal 37 (2): 202-217.

Macauley, Melissa [1998]. Social Power and Legal Culture. Litigation Masters in Late Imperial China. Stanford: Stanford University Press.

Masud, Muhammad Khalil - Messick, Brinkley - Powers, David (eds.) [1996]. Islamic Legal Interpretation. Cambridge: Harvard University Press.

Messick, Brinkley [1993]. The Calligraphic State. Textual Domination and History in a Muslim Society. Berkeley: University of California Press. 
Palmer, Alex [2017]. The Last Line of Defense. New York Times Magazine, July 30, 2017: 24-51.

Powers, David [2002]. Law, Society and Culture in the Maghrib, 1300-1500. New York: Cambridge University Press.

Rahman, Fazlur [1979]. Islam (2nd edition). Chicago: University of Chicago Press.

Rahman, Fazlur [1982]. Islam \& Modernity. Transformation of an Intellectual Tradition. Chicago: University of Chicago Press.

Ibn Rushd [1994]. The Distinguished Jurist's Primer (translated by Imran Ahsan Khan Nyazee). Second Volume. Reading: Garnet.

Schacht, Joseph [1964]. An Introduction to Islamic Law. Oxford: Clarendon Press.

Schluchter, Wolfgang [1979]. Max Weber's Vision of History. Berkeley: University of California Press.

Schluchter, Wolfgang [1981]. The Rise of Western Rationalism. Max Weber's Development History. Berkeley: University of California Press.

Schluchter, Wolfgang [1989]. Rationalism, Religion, and Domination. Berkeley: University of California Press.

Stein, Peter [1999]. Roman Law in European History. New York: Cambridge University Press.

Stern, Rachel E. [2017]. Activist Lawyers in Post-Tiananmen China. Law \& Social Inquiry, 42 (1): 234-251. Ibn Warraq [1998]. The Origins of the Koran. Classic Essays on Islam's Holy Book. Amherst: Prometheus Book.

Watt, Montgomery [1974]. The Formative Period of Islam. Edinburgh: Edinburgh University Press.

Watt, Montgomery [1994]. Muslim Creeds. Edinburgh: Edinburgh University Press.

Weber, Marianne [1975]. Max Weber. A Biography. New York: Wiley.

Weber, Max [1954]. On Law and Economy (edited and translated Max Rheinstein and Edward Shils). New York: Simon and Schuster.

Weber, Max [1958]. The Protestant Ethic and the Spirit of Capitalism. New York: Charles Scribner's Sons.

Weber, Max [1961]. General Economic History. New York: Collier - MacMillan.

Weber, Max [1964]. The Sociology of Religion. Boston: Beacon Press.

Wensinck, Jan [1932]. The Muslim Creed. Cambridge: Cambridge University Press.

Whitson, Sarah Leah [2017]. Saudi Arabia’s Shakedown. New York Times, December 1, 2017.

Toby E. Huff was born in Portland, Maine and has been living in the Boston area since 1960. His interest in history of science led to a life long interest in the problems of Arabic-Islamic science and the question of why modern science developed only in the West. These interests resulted in a major studie, The Rise of early Modern Science: Islam, China and the West (1993, 3rd edition 2017). While doing research on Islam, science and development, Huff lived in many predominantly Muslim countries all around the world. From the perspective of historical sociology, his research is based on works of Max Weber and Benjamin Nelson. 